\title{
Rural and Small Community Educator Responses to State Academic Standards
}

\author{
Carolyn Babione \\ Indiana University Southeast
}

\begin{abstract}
Rural and small town schools are in the midst of revising curriculum to meet state and national mandates. This article presents information gained from a two-year grant funded training program for rural teachers focusing on the Indiana state-mandated curriculum change. The context in which teachers teach and their prevailing attitudes and beliefs about students and learning shape how they respond to the state standards in their classrooms. Teachers respond to state standards through a "customized approach" based on personal philosophical orientations to teaching and learning.
\end{abstract}

Indiana has consistently set rigorous expectations for student learning (Indiana Department of Education, 2010). Integrating state standards into already established local school curriculum is a complex endeavor that brings added dimensions to the work of rural and small school teachers. While there is ample rhetoric regarding the value of standards-based curriculum, there is less understanding regarding rural and small community practitioner attitudes and beliefs as they modify teaching practices in response to these mandated standards. This study explored rural and small school teachers' responses and adaptations to state-mandated student standards.

\section{Literature Review}

The concept of rurality has been engrained in American culture for centuries. The term conjures images of farms, towns, and small spaces. However, no one definition clearly divides rural and urban entities: Many different definitions exist developed by different agencies and organizations (Rural Assistance Center, 2010). These multiple definitions involve boundaries, land-use, and shifts in populations, reflecting the multidimensionality of the term (Cromartie \& Bucholtz, 2008). For example, the National Center for Education Statistics (2010) differentiates towns and rural areas on the basis of their proximity to larger urban centers, while the Rural Housing Program delineates rural eligibility as areas with populations of less than 20,000 people (Cromartie \& Bucholtz, 2008). Approximately $19 \%$ of the total number of students enrolled in US public schools attends very small schools located in rural areas. Meeting the educational needs of rural children is a challenge. In Indiana alone, nearly four of ten Indiana public schools are located in rural areas (Johnson \& Strange, 2009).

\section{Changing Value of Smallness}

Much of the twentieth century, rural, small community, educational reform movement concentrated on redesigning small and rural schools to resemble their urban counterparts (Kannapel \& DeYoung, 1999; Kliebard, 2002). Generally, these initiatives resulted in school consolidations (DeYoung, 1995). However, in more recent years, the trend has changed to support smallness. Larger schools are increasingly being reorganized to resemble small community schools in efforts to connect with students and provide more individual attention (Learn, 2006; Meier, 1995). The Bill $\&$ Melinda Gates Foundation recently dedicated over $\$ 200$ million to reducing the size of U.S. high schools (Wasley, 2002).

Research on rural schools indicates high levels of overall satisfaction by teachers (Huysman, 2008), better connections between teachers and students (Blum, 2002). more opportunities for students (Mitchell, 2000), and lower violence, misbehavior, tardiness, and class cutting (Dinkes, Kemp, Baum, \& Snyder, 2009). Conditions traditionally associated with rural and small schools, such as poor educational conditions and limited economic development (Roscigno \& Crowley, 2001), higher dropout rates, lower percentages of adults with degrees (National Center for Education Statistics, 2007), and high rates of child poverty (Farmer et. al., 2006; Johnson \& Strange, 2007), have become acceptable trade-offs to the public for the perceived advantages.

\section{Mandates for School Change}

The No Child Left Behind Act (2001) has mandated school changes that have impacted rural and small school educational decision-making in varying ways. A broad range of academic performance has been associated with geographical differences and populations of students 
served (Eppley, 2009; Farmer et al., 2006; McCabe, 2006). The needs of rural communities reflect unique circumstances, and under these mandates, rural schools and communities lose their opportunity to define educational quality in ways that meet local needs (Eppley, 2009). Rural districts "face challenges with regard to the cultivation of a teaching force that possesses subjectmatter expertise, willingness to undertake difficult professional work at the local level, and attentiveness to rural practices and meaning" (Howley \& Howley, 2005, p. 4).

Much of the responsibility for instructional improvement mandated by the standards movement has been placed on the building principal. Accountability measures require principals to work with staffs on schoolwide professional development (Chance \& Segura, 2009). Farmer et al. (2006) emphasized the need for more professional development training and support for teachers with a focus on populations in these diverse rural settings. Huysman (2008) recommended that district professional development should include more active roles for district educators in efforts to increase their status and significance with other community stakeholders. Hickey and Harris (2005) reported that practitioners responded positively to professional development led by peer 'teacher leaders.'

\section{Rural Educators Adapting Teaching Strategies}

The debate about how rural and small schools respond to mandated standards to meet the educational needs of children continues (Howley, 2003; Lucas \& Fugitt, 2009). Some rural teachers report lack of curriculum flexibility and perceive shifts towards scripted drill and kill essential skills development in efforts to align curriculum with state testing (Powell, Higgins, Aram, \& Freed, 2009). Progressive teachers report using strategies, such as placebased education, to successfully integrate standards into curriculum relevant to local contexts (Jennings, Swidler \& Koliba, 2005). However, traditional curriculum approaches continue to persist in these settings (Howley, 2003).

The tremendous diversity in resources and needs of rural and small schools make it impractical to identify universal approaches to improve student performance. However, situated learning has relevance for the rural and small school teacher (Eppley, 2009) and many teachers report curriculum adaptations based on the contexts in which they teach (Howley \& Howley, 2005; Jimerson, 2004; Johnson \& Strange, 2005; Starr \& White, 2008) and customized approaches to mandated standards (Reigeluth, 1997).

\section{Building Community}

Hickey \& Harris (2005, p. 13) note "Collaboration should not be an option for teachers, but a professional responsibility." Adapting to new standards requires complex curriculum changes that may stretch small school practitioners' potential for collaboration beyond their limits. Educators in small schools are likely to wear more hats, have less access to professional development, teach outside their areas of expertise, experience professional isolation. and have more class preparations (Hickey \& Harris, 2005; Howley \& Howley, 2005; Johnson \& Strange, 2009; Mollenkopf, 2009).

According to Chance and Segura (2009), while rural settings have natural advantages for building community and collaboration for school improvement, such practices do not occur without effort. While many professional development initiatives support the sharing of practical knowledge (Elbaz, 1981), long standing school norms of autonomy (i.e., being independent) and congeniality (i.e., maintaining a friendly working environment) continue to inhibit collective and collaborative thinking and professional engagement among teachers (Fullan \& Hargreaves, 1996). Zeichner and Liston (1996) observed that teachers "uncritically accept this everyday reality in their schools and concentrate their efforts on finding the most effective and efficient means to solve problems that have largely been defined for them by this collective code" (p. 9). In many school settings, non-confrontation and risk avoidance tend to foster traditional practice over untested change (Howley \& Howley, 2005).

Community values are also factors to be considered in educational decision-making. Rural educators should understand the importance of building strong communities and trusting relationships with students and families (Meier, 1995; Sizer, 1996). Freeman and Anderman (2005) reported that the climate of the rural classroom has greater coherence and stability that in turn provide increased motivation for students to master academic goals. However, Huysman (2008) theorized that rural teachers experience professional and social role . confusion and the conflicting expectations can negatively affect job satisfaction.

The interest in rural and small school adaptations to the standards movement continues. Educators need opportunities to share with others as they modify curriculum to meet mandated standards. Training initiatives have focused on identifying 'teacher leaders,' included more input from participants, and emphasized the context and community of these schools in content and delivery. This study explores outcomes of a two-year grant that funded a teacher development initiative, and investigates how rural and small school teachers responded to mandated standards. Specifically, areas explored included the degree to which participants placed value on standards-based instruction; the consistency of 
instruction with respect to mandated standards; the importance of collegiality in the implementation of standards-based instruction; initiatives used to differentiate instruction and motivate learners towards the new standards, and parent knowledge and understanding of the mandates.

\section{Improving Teacher Quality Partnership Grant}

A two-year training grant was funded by the Indiana Commission for Higher Education to provide collaborative training for 20 educators from two rural, small community, public school corporations in a rural designated Indiana county, under the direction of a regional campus institution of higher education. Nineteen educators participated in the grant training in Year One. Four participants did not return for Year Two training and five new participants were added in Year Two to give a total of 20.

Math, English, and education faculty from the partnering university, along with school corporation special education personnel, facilitated the training. The training sessions were held after school hours and on Saturdays over a two-year period, generally for approximately five hour blocks of time. Thirteen training sessions were offered in Year One and 18 sessions were offered in Year Two. Attendance at training sessions ranged from 4 to 17 participants in Year One and 15 to 18 in Year Two. Participants reported many other responsibilities after school and on weekends that interfered with consistent attendance and participation in the training.

The grant training addressed five objectives: (a) curriculum alignment of Indiana standards, (b) crossdiscipline curriculum and instruction, (c) instructional modifications to include technology and behavior management, (d) collegial skills to build relationships, and (e) teacher inquiry action research. The two-year training included "think tank" discussions and professional development activities related to standards, capacity building with stakeholder groups, differentiated instruction, behavior management strategies, instructional strategies for assessment of students, and technology applications for instruction and assessment.

The training sessions were designed to engage grant participants in discussions of dilemmas, challenges, and paradoxes of teaching. To insure that the training captured the voice of participating teachers, active small and largegroup participation was utilized. Reflectivity was captured through journaling, responses to readings and group discussions, and reactions to scenarios and role taking experiences. Group reflectivity focused on narratives of schooling to explore contradictions in teaching and learning described by Clandinin and Connelly (1986). Together, participants joined as "critical friends" in professional support of one another, in "equal status' relationships between participants and the facilitators.

A follow-up study involving 18 of the original participants was conducted at the end of the two-year training period. Participants in the follow-up included 4 elementary teachers (including 2 special educators), 5 middle school teachers (including 2 special educators), 7 high school teachers (including 1 special educator), and 2 secondary building level administrators. Five participants were male and 13 were female. Their teaching experience ranged from 1-30 years. Three participants were identified as novice, in their first two years of teaching.

\section{Data Collection}

The grant director served as the primary researcher for the project. Various data sources were collected in two stages.

Stage 1. In stage 1, data were collected throughout the two-year training period, and included field note observations, participant work samples and writing responses, interviews, and written surveys. Participant work samples included quick-write reflections at each training session, writing responses to training assignments involving curriculum development, their evaluated student work samples, and short surveys conducted with participants at various times during the training.

Individual informal and formal, open-ended, audiotaped confidential interviews were conducted twice at the grant training site during the grant activities and once in the participants' school settings at the conclusion of the grant training to elicit attitudes and beliefs about the movement to standards-based curriculum. Each interview lasted approximately one hour, and interviews were recorded and transcribed for later coding and interpretation.

Stage 2. At the conclusion of the training, a final Likert-type survey was mailed to the 18 participants who agreed to take part in the follow-up study. Surveys were returned by 16 of the 18 participants ( $89 \%$ return rate), five of whom indicated they had participated in the grant for less than two years. Three participants were identified as novices, in their first two years of teaching. The final survey included responses about integrating standards, the impact of standards on student learning, understanding standards, the value and importance of collegiality, the value of using a range of instructional strategies, student motivation and parental knowledge.

\section{Data Analysis}

A grounded theory approach to data analysis was chosen, in which theory emerges from the data gathered through ongoing inductive processes; emerging insights are re-analyzed for additional insights (Corbin \& Strauss, 2008; Glasser \& Strauss, 1967). Data were collected, 
compared and analyzed throughout stage $I$ by the grant director. Data sources were triangulated, compared and cross-checked for consistency of information (Patton, 1990). All data, including interview transcripts, field notes, and documents were subjected to qualitative analysis, which included categorizing and seeking patterns and themes. Through constant comparative analysis of categories, themes, and tentative explanations, a set of questions developed to offer insight into this exploratory study.

The limitations to the study included the small sample size, the movement of participants in and out of the study, and the lack of attendance by participants at training sessions. However, the findings discussed below are believed to add to the body of literature on rural and small school teaching within the mandated standards movement.

\section{Findings}

The first question addressed in this study was the consistency of implementation of standards-based instruction. The second explored the degree to which participants placed value on standards-based instruction. Other areas investigated were the degree of collegiality needed to align standards, initiatives towards differentiating instruction, motivating learners towards the new standards, and parent knowledge and understanding of the mandates.

\section{How Consistent is the Implementation of Standards- Based Instruction?}

Year One training goals/objectives focused on understanding English language arts and mathematics standards. Grant participants collaborated with English and math content faculty to review and analyze student standards, engage in curriculum alignments, and backmap teaching activities to standards.

Although there was a presumption that teachers in the same building would have a similar familiarity with state standards, some participants had previously chaired school improvement teams or worked in state study groups. This resulted in variations in the knowledge level of participants about state mandated standards as they began the training.

While prior to the grant project several participating schools had already established instructional planning and learning communities, school planning times for working on horizontal and vertical curriculum mapping, and initiated specific standards-based professional development activities, other schools within the same districts were less advanced. All participants reported growth in knowledge of standards at the end of year one with the exception of one teacher who indicated she realized she was less knowledgeable than she first thought herself to be.

\section{What Value do Educators Place on Standards-Based Instruction?}

Participants' perceptions of how the standards should be addressed in their rural schools were varied. Some participants described attempting to teach all standards. Others suggested they were teaching the 'most important standards,' relying on previous teaching experience to determine which standards to teach. A third group reported teaching thinking and process skills, and only indirectly teaching the actual state standards. Two participants described using place-based curriculum, building teaching around local interests and student experiences.

Participants indicated that teachers were not motivated by the standards themselves but by the accountability that has accompanied the standards movement through the state-mandated yearly testing. Standards were viewed most useful when a previous lack of uniformity existed between teachers at the same grade levels. The standards movement had created a unified grade-level curriculum without requiring teachers to collaborate on the curriculum design.

This adaptation to a more standard, common curriculum was perceived by the special education teacher participants as especially beneficial to special needs students. On the other hand, several participants, although they indicated they were striving to effectively teach to the standards, held personal views that the standards were a nuisance, inhibiting creativity and pushing lowachieving students out of schools although they were striving to effectively teach to the standards. From anecdotal comments during the training sessions, and noted in several of the individual interviews conducted at the conclusion of the study, the participants knew teaching colleagues who viewed the state standards as another set of ignored guidelines gathering dust in the central office with little relevance to their own teaching and instruction.

Data from the mail-back survey, conducted at the conclusion of Year Two, indicated that $100 \%$ of respondents agreed or strongly agreed that a standardsbased curriculum defines a challenging course of study and sets a minimum level of achievement and proficiency for all students; $73 \%$ agreed or strongly agreed that while state standards establish a minimum level of learning, this minimum often becomes the maximum; $64 \%$ agreed or strongly agreed that standards control a teacher's choice of curriculum and instruction, and $64 \%$ agreed or strongly agreed that standards motivate teachers to stay focused and result in less 'down time' in the classroom.

While some participants believed that the standards movement supported active-learning strategies, these 
educators also perceived standards as broad enough to allow flexibility in instructional strategies. Teachers, who believed in the importance of teaching essential and basic skill development, viewed the state standards as a mandate for more teaching of basic skills. While these traditional teachers saw the value of active learning, they were quick to add statements like, "but I'm not the creative type and therefore I do not utilize these teaching strategies." Participants maintained their original teaching strategies throughout the standards-based training. Traditional teachers remained committed to teaching traditional, basic skills, and creative teachers continued to value and seek out instructional strategies for active learning and real-life experiences. Teachers taught the standards-based curriculum in the same ways in which they had previously taught, using the mandated standards to support their preferred teaching strategies and styles.

The three novice teacher participants held some of the most positive attitudes about the standards-based movement. They believed their recently completed teacher education programs had prepared them to teach standards-based curriculum, and more importantly, that state standards provided clear direction to them as novice teachers. On the mail-back survey, $91 \%$ of all respondents agreed or strongly agreed that state standards were especially beneficial to new teachers.

On the mail-back survey, $82 \%$ of respondents agreed or strongly agreed the administrators' role in encouraging and supporting the implementation of standards-based curriculum was key. Teachers wanted their administrators to be more assertive in overseeing adherence to state standards. On the other hand, participating administrators believed more teacher-leadership was needed to support their administrative efforts. Teacher participants reported that effective administrative strategies included facilitating curriculum alignment and mapping, differentiated instruction and opportunities for staff collaboration.

\section{How Important is Teacher Collegiality in Implementing New Standards?}

The peer coaching, critical friend concept was a major goal and outcome for both years of the grant. Grant activities provided opportunities for participants to work collaboratively with colleagues and the community to clarify and articulate Indiana's student academic standards. Participants engaged in mock peer coaching activities, utilizing a third person to monitor dialogue and provide feedback on the process. The grant provided two substitute teaching days each year to utilize peer coaching. Participants valued the grant training time devoted to developing this collegiality. They noted that although several schools were located in close proximity to each other, often in adjacent buildings, there was a lack of opportunities during the school day for professional dialogue with other educators.

The provision of time to develop collegiality with others was paramount to these busy rural and small school educators. Although it is often assumed that rural community schools engage in more interaction and collaboration than larger districts, even after two years of training, participants still wanted to identify additional professional development that would sustain the collaboration they were experiencing through the grant training activities. Responses from the mail-back survey indicated that $91 \%$ agreed or strongly agreed that the state standards movement would require ongoing, high quality professional development for teachers; $100 \%$ of respondents agreed or strongly agreed that teacher isolation is a barrier to school renewal efforts such as the standards movement; $82 \%$ of respondents agreed or strongly agreed that the standards movement is held back by the lack of planning time in the workday for educators, and $91 \%$ agreed or strongly agreed that standards call for teacher collaboration around a common set of educational guidelines.

Grant participants consistently valued collegial activities, indicated by interview statements such as: "The critical friend activity should be one of the more valuable tools helping in the nuts and bolts of teaching." "I think it's really brought schools together, especially within our county." "Before, I didn't know any teachers from any other schools so it has been nice to go to [school name removed] and be able to see different people." "It was extremely beneficial to work amongst a group of seasoned educators who are dedicated to becoming more proficient in their fields." "Sharing rubrics from other schools made me realize our school is on the right path in generating useful rubrics." Collegiality is not a given in rural and small school settings, but is highly valued by these educators.

\section{What Impacts Educators' Readiness for Instructional Differentiation?}

Differentiating instruction to meet the needs of all learners, including students identified for special education, was a primary focus of the grant activities in Year Two. Participants studied new teaching strategies to engage students, including active communication through questioning techniques, teaching resources based on multiple intelligences aligned with their content standards, curriculum integration, and curriculum compacting. Interview comments at the conclusion of the study indicated that participants valued learning more about developmental readiness and differentiated instructional strategies. Comments included "an appreciation and understanding of how the Indiana standards in math, LA and science are founded on developmental readiness. It makes me a great deal more 
secure in my planning," and "Because of an increased awareness of developmental readiness, I have altered several of my expectations regarding content and presentation of several of $m y$ units...I also hav' a greater awareness that some of my past expectations of students were not realistic."

General education participants had greater difficulty coming to terms with differentiating instruction, and the inclusion of special education teachers in the project brought valued insights regarding individualized instruction for special needs populations. Two special education consultants facilitated several training sessions on topics ranging from case conferences, behavior management plans, and individualizing instruction based on IEP documentation.

Curriculum integration across content areas was stressed in both years of training. While cross-disciplinary teaching was widely used by elementary and some middle school participants, secondary teachers were clearly more reluctant to prepare integrated curriculum.

Several secondary participants indicated their resistance was due to the fact that they lacked an understanding of content standards outside of their fields. The separateness of subject area standards (math, English, science) contributed to the lack of importance placed on secondary curriculum integration. These participants also noted that the sheer number of competencies to be covered was also a barrier. On the mail-back survey, $91 \%$ agreed or strongly agreed that test preparation has become the 'defacto' curriculum in many schools, suggesting that there is little perceived time to teach differentially.

Participants also believed that differentiating instruction required appropriate materials. The grant supported the purchase of over $\$ 1000$ for materials for each participant, including the administrators. Some participants ordered grant materials for their own classrooms while others pooled their resources and ordered materials that benefited several classrooms in their buildings. Participants ordered multiple copies of children's literature, math games and manipulatives to support standards-based teaching. On the mail-back survey, $82 \%$ of responders agreed or strongly agreed with the statement, "A drawback to the standards movement is the lack of funds for appropriate teaching materials needed to adequately teach standards."

\section{Motivating Students towards High Stakes Testing}

If students are to achieve learning objectives they must be motivated. Establishing classroom practices and positive student behaviors are key factors in creating an effective learning environment. Behavior management in this project was addressed through several special education consultant presentations. Evaluation of current practices was based on observations, prepared descriptions of behavior management logs and reporting procedures. There was wide variability in how teachers and schools utilized behavior management to promote effective student learning. Some schools had welldeveloped policies and procedures whereas others did not.

It was interesting to note that management strategies described by participants at the beginning of the second year of training rarely acknowledged that curriculum changes could impact classroom management. Participants described strategies such as contacting parents, and proximity to students as strategies to manage and motivate students, giving little attention to strategies such as cooperative learning and flexible grouping, providing students with more time to meet the standard, developing or revising instructional units, finding ways to integrate the content into another subject area, or engaging students in self-assessment to share responsibility for learning.

The lack of student motivation to do well on high stakes tests continued to be cited as a major concern for a number of participants throughout the grant period. The mail-back survey indicated that $100 \%$ agreed or strongly agreed that, "Motivation is more complex than telling students they must pass a high stakes exam." Only a few participants indicated they addressed student motivation by focusing on teaching students how to live well, actively, and fully in their communities.

\section{How Knowledgeable Are Parents about the Standards Movement?}

The importance of role of parents in their children's education is widely recognized. However, parents are frequently unaware or have little understanding of new educational initiatives or of the role they can play in educational outcomes. Consequently parental engagement was a major objective in the first year of training. Participants read extensively about involvement of parents and community. They prepared and conducted a parent survey to determine parent understanding of student standards and utilized technology applications to report their findings. Groups' comments included "It was noted that not only do the majority of the parents not understand state standards, they do not understand the ISTEP." "This is a major problem when the school needs the understanding and support of parents," and "The outcome of our discussion included ways in which to inform the parents and be certain of their understanding."

Participants believed in the importance of parental involvement but acknowledged that many parents were still unaware of the significance of standards and that their schools were grappling with this issue. On the mailback survey, while $82 \%$ of responders agreed or strongly agreed that state testing provides parents and teachers with information about patterns of strengths and weaknesses of their students, $82 \%$ also disagreed or 
strongly disagreed that parents are knowledgeable and well informed about state standards and their child's performance levels. Study participants often seemed at a loss regarding how to better communicate standards to parents, especially to those parents who are dealing with life issues that often interfere with parenting responsibilities related to schooling.

\section{Discussion}

Teachers in rural and small school settings hold attitudes and beliefs about the mandated standards movement. There is wide variability with respect to their understandings and experiences with state mandated standards within and across building-level learning communities, the degree of acceptance of these standards by those involved, and individual responses to these mandates.

While test preparation has become a crucial aspect of curriculum, educators in this study often responded with "customized approaches" based on their personal attitudes and beliefs about teaching and learning, similar to the findings of Reigeluth (1997). Practitioners interpreted standards through their own beliefs and practices, resulting in variability within school settings for individually preferred teaching approaches and strategies. While variability in instructional strategies in rural and small school settings has also been reported by others (Lucas \& Fugitt, 2009; Powell et al., 2009), findings from this study indicated mandated standards are broadly interpreted to support what individual teachers think and believe about teaching and learning.

The standards require teacher collaboration around a common set of educational guidelines. However, the participants believed that teacher isolation is a major barrier to their school renewal efforts. Collegiality does not happen naturally in these smaller, busy, school settings, to the degree one might expect. Educators wear multiple hats and have limited time in their busy school days for curriculum alignment and planning. With little time for collegiality, novice teachers valued standards as guidance for what should be taught, while experienced teachers valued the standardization of curriculum as a mandate for colleagues to follow when there is no schoolwide initiative or support in place for building a common body of knowledge. Chance and Segura (2009) also reported that collaboration for school improvement does not occur without effort. School schedules and norms that inhibit collective and collaborative engagement among educators continue to exist (Fullan \& Hargreaves, 1996; Zeichner \& Liston, 1996).

Teacher participants believed that ongoing professional development was needed and that administrators were key to motivating teachers to adhere to standards-based curriculum. Accountability measures require more from principals regarding school-wide professional development (Chance \& Segura, 2009). However, administrators in this study thought that teachers, as content area experts, should also assume stronger leadership to support the standards movement. Huysman (2008) also suggested that active roles in professional development by teachers could increase their status and significance.

In this study, the availability of teaching materials needed to effectively teach standards, the specific needs and motivations of individual learners in these settings, and how knowledgeable practitioners and parents were about mandated standards in general varied from school to school. Uniqueness found in small and rural context settings has also been reported by others (Howley \& Howley, 2005; Starr \& White).

\section{Conclusion}

Rural and small school educators are experiencing increased pressure to achieve student proficiency. The NCLB act (2001) has contributed to an oversimplified assumption that state standards and high stakes testing automatically increase student motivation and improve teaching practice. One size fits all professional development for the rural and small school setting does not take into account the wide variability found in these settings and the stronghold that previous successes in teaching within these contexts holds for practitioners.

Professional development should be flexible to meet the needs of specific rural and small school educators with regard to differences in background preparation, preferred teaching styles, individual needs of learners. Long-term participation in standards-based training that respects the knowledge and expertise of practitioners increases positive attitudes about standards-based reform and leads to more buy-in for the standards-based initiative. Forced curriculum alignment is superficial when it does not challenge practitioners and the larger community in authentic dialogues about learning and teaching. Effective standards-based training provides opportunities for engagement in professional dialogue with other educators on attitudes and beliefs about best practices in teaching and learning, strategies for engaging parents and community, and time for collaboration and curriculum planning.

\section{References}

Arnold, M., Newman, J., Gaddy, G., \& Dean, C. (2005). A look at the condition of rural education research: Setting a direction for future research. Journal of Research in Rural Education, 20(6). Retrieved May 12, 2010, from http://jrre.psu.edu/articles/20-6.pdf Barley, Z., \& Beesley, A. (2007). Rural school success: What can we learn? Journal of Research in Rural 
Education, 22(1). Retrieved May 12, 2010, from http://jrre.psu.edu/articles/22-1.pdf

Blum, R. (2002). The untapped power of schools to improve the health of teens. Minneapolis, $\mathrm{MN}$ : Center for Adolescent Health and Development, University of Minnesota Press.

Chance, P., \& Segura, S. (2009). A rural high school's collaborative approach to school improvement. Journal of Research in Rural Education, 24(5). Retrieved May 13, 2010, from http://jrre.psu.edu/articles/24-5.pdf

Clandinin, D., \& Connelly, F. (1986). Rhythms in teaching: The narrative study of teachers' personal practical knowledge of classrooms. Teaching and Teacher Education, 2(4), 377-387.

Corbin, J., \& Strauss, A. (2008). Basics of qualitative research $\left(3^{\text {rd }}\right.$ ed. $)$. Thousand Oaks, CA: Sage.

Cromartie, J., \& Bucholtz, S. (2008). Defining the "rural" in rural America. Amber Waves. Retrieved May 18, 2010,from http://www.ers.usda.gov/ AmberWaves/June08/Features/RuralAmerica.htm

DeYoung, A. (1995). The life and death of a rural American high school. New York: Garland.

Dinkes, R., Kemp, J., Baum, K., \& Snyder, T. (2009). Indicators of school crime and safety: 2009. Washington, DC: National Center for Educational Statistics, U.S. Department of Education.

Elbaz, F. (1981). The teacher's 'practical knowledge:' Report of a case study. Curriculum Inquiry, $11(1), 43$ 71.

Eppley, K. (2009). Rural schools and the highly qualified teacher provision of No Child Left Behind: A critical policy analysis. Journal of Research in Rural Education, 24(4). Retrieved may 18, 2010, from http://jrre.psu.edu/articles/24-4.pdf

Farmer, T., Leung, M., Banks, J., Schaefer, V., Andrews, B., \& Murray, R. (2006). Adequate yearly progress in small rural schools and rural low-income schools. The Rural Educator, 27(3), 1-7.

Freeman, T., \& Anderman, L. (2005). Changes in mastery goals in urban and rural middle school students. Journal of Research in Rural Education, 20(1). Retrieved May 18, 2010, from http://www.umaine.edu/jrre/20-1.pdf

Fullan, M., \& Hargreaves. A. (1996). What's worth fighting for in your school? New York: Teachers College Press.

Glaser, B., \& Strauss, A. (1967). The discovery of grounded theory: Strategies for qualitative research. New York: Aldine.

Goetz, J. \& LeCompte, M. (1982). Problems of reliability and validity in ethnographic research. Review of Educational Research, 52(12), 31-60.

Hickey, W. \& Harris, S. (2005). Improved professional development through teacher leadership. The Rural Educator, 26(2), 12-16.
Howley, A. (2003). Tried and true: The rural school curriculum in the age of accountability. Educational Forum, 68(1), 14-23.

Howley, A., \& Howley, C. (2005). High-quality teaching: Providing for rural teachers' professional development. The Rural Educator, 26(2), 1-5.

Huysman, J. (2008). Edward W. chance dissertation award for doctoral research in rural education. The Rural Educator, 29(2), 31-38.

Indiana Department of Education (2010). Welcome to Indiana's academic standards and resources. Retrieved May 18, 2010, from http://dc.in.gov/Standards/Academic Standards/index.shtml

Jennings, N., Swidler, S., \& Koliba, C. (2005). Placebased education in the standards based reform era: Conflict or complement? American Journal of Education, 112(1), 44-65.

Jimerson, L. (2004). The devil is in the details: Rural sensitive best practices for accountability under no child left behind. Washington, DC: Rural School and Community Trust.

Johnson, J., \& Strange, M. (2007). Why rural matters 2007: The realities of rural education growth. Washington, DC: The Rural School and Community Trust.

Johnson, J., \& Strange, M. (2009). Why rural matters 2009: State and regional challenges and opportunities. Washington, DC: The Rural School and Community Trust.

Johnson, J., \& Strange, M. (2005). Why rural matters 2005: The facts about rural education in the 50 states. Arlington, VA: Rural School and Community Trust.

Kannapel, P., \& DeYoung, A. (1999). The rural school problem in 1999: A review and critique of the literature. Journal of Research in Rural Education, 15, 67-79.

Kliebard, H. (2002). Constructing the concept of curriculum on the Wisconsin frontier: How school restructuring sustained a pedagogical revolution. In H. Kliebard (Ed.), Changing course: American curriculum reform in the $20^{\text {th }}$ century (pp. 7-23). New York: Teachers College Press.

Learn, S. (2006, October 3). Success with the smallschool model. The Oregonian. Retrieved May 12, 2010, from http://www.lexisnexis.com.oberon ius.edu/us/lnacademic/frame.do?reloadE

Lucas, D., \& Fugitt, J. (2009). The perceptions of math and math education in Midville, Illinois. The Rural Educator, 3l(1), 38-54.

McCabe, M. (2006, January 5). State of the states. Education Week, 25(17), 78-90.

Meier, D. (1995). The power of their ideas: Lessons for America from a small school in Harlem. Boston, MA: Beacon Press. 
Mitchell, S. (2000). Jack and the giant school. The New Rules, 2(1), 1-10. Retrieved May 21, 2010, from http://www.newrules.org/journal/nrsum00 schools.htm

Mollenkopf, D. (2009). Creating highly qualified teachers: Maximizing university resources to provide professional development in rural areas. The Rural Educator, 30(3), 34-40.

National Center for Education Statistics. (2010). Navigating resources for rural schools. Retrieved from http://nces.ed.gov/surveys/ruraled/page2.asp

National Center for Education Statistics. (2007). Status of education in rural America. Washington, DC: U. S. Department of Education.

No Child Left Behind Act of 2001. Pub. L. No. 107-110, S901, 115 Stat. 1425 (2002).

Patton, M. (1990). Qualitative evaluation and research methods ( $2^{\text {nd }}$ ed.). Newbury Park, CA: Sage.

Powell, D., Higgins, H., Aram, R., \& Freed, A. (2009). Impact of No Child Left Behind on curriculum and instruction in rural schools. The Rural Educator, 31(1), 19-28. .

Reigeluth, C. (1997). Educational standards: To standardize or to customize learning? Phi Delta Kappan, 79(3), 202-206
Roscigno, V., \& Crowley, M. (2001). Rurality, institutional disadvantage, and achievement/attainment. Rural Sociology, 66(3), 268293.

Rural Assistance Center. (2010). What is rural? Frequently asked questions. Retrieved May 4, 2010, from http://www.raconline.org/info_guides/ ruraldef/ruraldeffaq.php

Sizer, T. (1996). Horace's hope. Boston: HoughtonMifflin Press.

Starr, K., \& White, S. (2008). The small rural school principalship: Key challenges and cross-school responses. Journal of Research in Rural Education, 23(5). Retrieved May 12, 2010, from http://jrre./psu.edu/articles/23-5.pdf

Wasley, P. (2002). Small classes, small schools: The time is now. Association for Curriculum and Development, 59(5), 6-10.

Zeichner, K., \& Liston, D. (1996). Reflective teaching. Mahwah, NJ: Lawrence Erlbaum. 